B.A.J. 12, III, 729-730 (2006)

\title{
MEMOIR
}

\section{PETER NIGEL STUCKEY CLARK}

Peter Clark was born on 31 January 1947, the only son of Kenneth and Betty Clark. He was educated at King's College School, Wimbledon, and read mathematics at University College, Oxford, graduating with a double first in 1968. Apart from his outstanding academic record at Oxford, he also played a leadership role in the Christian Union, continuing a pattern of active Christian service which began in his early years at the Wimbledon Crusader Class.

Membership of Crusaders was important to Peter in another way, as his future wife Lynda was the daughter of Harold Smith Boyes, the leader of the Wimbledon Crusader class from 1956 onwards. Peter and Lynda were married at Wimbledon Baptist Church in the summer of 1969, and in the following years were blessed with three children - Rachel, Daniel and Ben.

On coming down from Oxford, Peter joined the Prudential in the Overseas 1 Section. He took and passed his first actuarial examination within weeks of joining, and continued his rapid progress through the exams to qualify in the April 1971 diet, after just $2 \frac{1}{2}$ years.

In June 1976 Peter moved to Vanbrugh Life, a subsidiary of the Prudential, and, with added responsibility, gained experience in a more senior actuarial role. He returned to the Prudential, working again on the overseas side, and in 1983 had his first visit to East Africa, which was the catalyst for the development of a passion for Africa which lasted throughout the rest of his life.

After qualifying as a Fellow, Peter was soon involved as a tutor for the Institute of Actuaries and later as an examiner. In 1981 he was appointed as the Institute's Membre Suppléant on the Groupe Consultatif des Pays des Communautés Européennes, and he continued as one of the Institute representatives for 25 years, becoming the Membre Titulaire on John Martin's retirement from the Groupe in 1997. He was elected Second Vice-Chairman of the Groupe in 1998, and progressed to become Chairman of the Groupe in 2000-2001.

Peter served on the Council of the Institute of Actuaries for three terms of five years each, spanning the period from 1987 to 2004. He was Honorary Secretary in 1989 to 1991, VicePresident in 1994 to 1996 and President of the Institute from 2000 to 2002. His last senior role in the U.K. Actuarial Profession was as Chairman of the International Committee.

He was also active in the International Actuarial Association (IAA) and chaired the Member Services Committee, which gave him a seat on the Executive Committee. He was an enthusiastic member of the Advice \& Assistance Committee and of the IAA Fund Committee, offering him more opportunities to support the development of the profession in actuarially developing countries, especially in Africa. He was President-elect of the IAA, and was due to become President for the year 2007.

He served as Member for Personnel for the U.K. Actuarial Profession for a number of years, in which capacity he was closely involved in staffing issues. Peter was well-known amongst the Institute staff for being one of the most caring and personally involved of those ever to fulfil this role. He took his responsibilities seriously and took a great interest in individual members of staff, continuing to visit Napier House in Oxford on a regular basis long after he had ceased to have any formal responsibilities for staff oversight.

Peter did not just serve on committees and hold high office in the profession. He made a real difference to the Institute. He was an enthusiastic supporter of the regional actuarial associations and played an active role himself in the Bristol Actuarial Society.

He was an excellent communicator and public speaker, and made enhancing communication one of the key themes of his Presidency. He spoke with great clarity and with a restraint on speed of delivery to ensure that he could be understood by non-native English speakers, whom he actively sought to encourage to make a greater contribution to the profession internationally. $\mathrm{He}$ 
was also one of the few British members of the Institute who could give a lecture and conduct business in French.

Apart from communication, the other two major themes of his Presidential address were culture and companionship, both of which epitomised Peter's own contribution to the profession, which included chairing the two most senior dining clubs of the profession, Gallio Club (1999/ 2000) and The Actuaries' Club (2005/06). He appeared always to be well-organised, and managed, apparently effortlessly, to balance his many competing priorities. He was meticulous in his planning and in managing his time, and expected those with whom he lived and worked to meet similarly exacting standards.

He was someone in whose presence one could always feel comfortable, a good friend, ever ready with a humorous remark, business-like and yet affable, down to earth and yet visionary. He was a conciliator and consensus builder by nature, not taking extreme positions, but quietly and effectively getting things done and persuading others to do the same. He loved his profession.

In 1991, after 23 years at the Prudential, he joined Sun Life as director and chief actuary, a post which he held until his retirement in 2002 , by which time the company had become AXA Sun Life. After his retirement, or 'change of life' as he preferred to call it, Peter worked as an adviser to the Financial Services Authority (one of their so-called 'grey panthers'). He also had a part-time teaching position in the Department of Statistics at Oxford University and a close association with the Institute of Ageing, also in Oxford. He held non-executive director positions with Ecclesiastical Insurance Office, Nationwide Life and Western Provident Association.

Peter had continued to play an active role in the church, with many years as leader of a crusader class and then as a deacon of Worcester Park Baptist Church. When the family moved to Nympsfield in Gloucestershire in 1996, Peter became a lay preacher at Wotton Baptist Church, and often preached in various local parish churches, later also becoming church warden of Nympsfield parish church. In 2004 the family moved to Ampfield in Hampshire, where they were also able to accommodate Peter's father-in-law Harold until his death a short while before Peter's.

Peter and Lynda became very involved in the Dagoretti project, working with indigenous people giving hope and a future to street children in Nairobi, Kenya. Through this involvement they took under their wing and supported a new son and brother, Gilbert, who became an outstanding athlete in his native Kenya and who also competed for the British Armed Forces.

The family's close association with Africa will continue through the Peter Clark Memorial Trust, through which the money given in memory of Peter will be utilised to support projects for street kids and the education of underprivileged Africans to become actuaries, in both Kenya and South Africa.

Peter died suddenly and unexpectedly on 11 June 2006, leaving a great void in his family and among all those who knew him. Many things which he wanted to do, including his forthcoming Presidency of the IAA, were not to be. However, he achieved so much in his life that it is right to celebrate what he did rather than regret what might have been. He will be remembered with huge affection by the profession and by all who worked closely with him, as well as by many whose lives were touched by Peter's love and lifelong Christian witness and service.

CHRIS DAYKIN 